\title{
Gaziantep Yöresi Geleneksel Eğlence Hayatında Bir İletişim Örneği Olarak Kadın Toplantı ve Eğlencelerinde Oynanan Oyunlar
}

\author{
Esin Dedemoğlu ${ }^{1}$
}

\author{
Deniz Dedemoğlu Köktan²
}

\begin{abstract}
$\ddot{O} z$
Insan sosyal bir varlık olarak çevresiyle düzenli veya düzensiz, bilinçli ya da bilinçsiz bir iletişim süreci içerisindedir. Insanlar çevrelerinde olup bitenlerden, birbirlerinin etkinliklerinden iletişim sayesinde haberdar olurlar. Haberleşme, bilgi-duygu-fikir paylaşımı insanoğlunun varoluşundan bu yana akıp giden bir süreci temsil eder ve bu süreç zorunludur. Üretmeyen, paylaşmayan, haberleşmeyen, anlaşmayan, etkilemeyen, etkilenmeyen insan çevresiyle bütünleşemez, toplumun parçası olamaz. Toplumun parçası olamayan insanın tek başına ihtiyaçlarını karşılaması veya duygusal olarak doyuma ulaşması oldukça zordur.

Geçmişi insanlık tarihi kadar eski olan oyun kavramı, özellikle çocukluk döneminde bireyi hayata hazırlama, ergenlik ve erişkinlikte eğlence, yarı̧̧ma, fazla enerjinin atılması, fiziksel-ruhsal rahatlama vb. işlevleriyle karşımıza çıkmaktadır. Müzikli-müziksiz oyunlar, araçlı-araçsız oyunlar, dramatik oyunlar, zekâ oyunları, beceri ve güç oyunları insanların boş vakitlerini değerlendirmeleri ve rahatlamalarının yanı sıra iletişimsel unsurları içinde barındırması ve bireylerin iletişim becerilerini geliştirmeleri açısından önemlidir. Çalışmada, geçmişte Gaziantep yöresi kadın toplantı ve eğlencelerinde oynanan oyunlar ve bu oyunların iletişim boyutu üzerinde durulmuştur.
\end{abstract}

Anahtar Sözcükler: Oyun, İletişim, Kültür, Gelenek, Eğlence

\section{Games Played in Women Gatherings and Pastimes as an Example of Communication in Gaziantep Region Traditional Entertainment Life}

\begin{abstract}
As a social creature, people are in a periodic or aperiodic, conscious or unconscious communication process with one another. People become informed of what happens around them and their activities with the help of communication. Communication, information-emotion-idea sharing represent an ongoing process since the existence of human beings, and this process is obligatory. A person who does not produce, share, communicate, understand, affect, become affected cannot be a part of the society. And it is quite hard for a person who cannot become a part of the society to fulfil his needs alone and achieve satisfaction emotionally.

The concept game, which is as old as the history of humanity, appears with its functions of preparing an individual for life especially during childhood, amusement during adolescence and adulthood, competition, getting rid of excessive energy, physical-mental relaxation, etc. Games with or without music, with or without tools, dramatic games, mind games, skill and power games are important since they contain communication elements in addition to enabling people to spend their free time and develop their communication skills. The study is about the games played in the women gatherings and entertainments of Gaziantep region and the communication aspect of these games.
\end{abstract}

Keywords: Game, Communication, Culture, Tradition, Entertainment

Gaziantep Üniversitesi, MYO Radyo Televizyon Teknolojileri Bölümü Eposta: dedemoğlu@gantep.edu.tr

2 Sakarya Üniversitesi, Devlet Konservatuarı THO Bölümü Eposta: ddeniz@sakarya.edu.tr 


\section{Giriş}

Araştırmanın konusu, Gaziantep Yöresi geleneksel eğlence hayatında kadın toplantı ve eğlencelerinde oynanan oyunların iletişim yönüdür. Oyun oynamak yalnızca eğlenmek ya da hoşça vakit geçirmek için yapılan bir etkinlik değildir. Oyunun sosyal boyutu, birleştirici yönü, geçmişten bugüne, bugünden geleceğe insan yaşamına ait hemen her unsuru taşıyıcı özelliği, eğlendirme işılevinin çok daha ötesindedir. Bu yönüyle oyunlar, taşıdıkları mesajlar açısından da ele alınmalıdır.

Bu çalışmada, Gaziantep Yöresi geleneksel eğlence hayatında kadın toplantı ve eğlencelerinde oynanan oyunların birer iletişim aracı olarak nasıl bir role sahip oldukları değerlendirilmiştir. Çalışmada sunulan bilgi ve bulgular 1şığında geçmişte sosyal yaşamın önemli eğlence unsurları içerisinde yer alan kadın oyunlarının, ezgi-söz-hareket bütününde iletişimsel özelliklerinin ortaya konulması amaçlanmıştır.

\section{İletişim}

İnsan yaşamı, iletişim üzerine kurulu karmaşık bir ilişkiler dizgesine sahiptir. Doğumundan ölümüne kadar çevresiyle paylaşım, aktarım, haberleşme vb. yollarla bağ kuran insanoğlu için iletişim, hayatın zorluklarını kolaylaştırmada başvurduğu en etkili yol ve yöntemdir. İletişimle ilgili bugüne kadar yapılmış binlerce tanım olmasına rağmen, bu tanımların her biri iletişim kavramının ancak bir ya da birkaç yönüne vurgu yapabilmektedir. Bunun temel sebebi işlev ve özellikleri açısından çok formlu, çok geniş bir alana sahip olmasıdır. İletişime dair bugüne kadar yapılmış pek çok tanımdan konumuza en yakın olanlarının paylaşılması yarar sağlayacaktır.

"İletişim; duygu, düşünce veya bilgilerin akla gelebilecek her türlü yolla başkalarına aktarılmasıdır" (Baltaş, 2007, s.19). "İletişim bilginin, fikirlerin, duyguların, becerilerin vb.nin simgeler kullanılarak iletilmesidir. İletişim, bir anlam arama çabasıdır. İletişim, simgeler aracılığıyla bir kişiden ya da gruptan diğerine bilginin, fikirlerin veya duyguların iletimidir" (Tutar, 2004, s.6). İletişimin gerçekleşmesi için bir tarafta bir şey iletmek isteyen yani anlam üreten bir kişinin(kaynak); diğer yanda da gönderilen iletiyi almaya ve algılamaya hazır olan ve kaynakla aynı anlamı üreten ve tüketen bir diğer kişinin(hedef) var olmasını gerektirir. "İletişim sürecinde kaynak ve hedef birbirleriyle hem gönderilen ileti veya anlam hem de bu ileti veya anlamı taşıyan bir araç (kanal) üzerinden bağlanmaktadır" (Gökçe, 2006, s.27). İletilen her mesaj anlam içerir. Bu anlam, içinde bulunulan duruma, ortama, olaya göre farklılık gösterir. İletiler amaca uygun anlamlar taşırlar. Ya da bazen amaçsız ve bilinçsiz olarak gönderilebilirler. İletişimin kontrollü olması; iletiyi gönderen ve alanın bu sürecin farkında olması ve belli bir amaca yönelik hareket etmeleriyle mümkündür (Yanık, 2010, s.9). Bu doğrultuda iletişim sürecinde anlaşmayı sağlayan en önemli etken, paylaşılan mesajlara ortak anlamların yüklenmesidir. Ortak anlamlara sahip olmak; ancak kültür kavramı ile açıklanabilir.

"Kültür, kuşaktan kuşağa geçen ve toplumdan bireye kazandırılan bir yaşama biçimidir. Toplum tarafından yaratılmış olan ayrıntılı değerler ve anlamlardan oluşan simgesel bir toplum çevresi ya da Williams'ın ifadesiyle, "bir anlamlandırılma sistemidir" (Gökçe, 2006, s.10). Kültür, halkın sahip olduğu bilgi ve bu bilgilere dayanarak ürettiği araçlardır. Yani bir halk ne kadar bilgi ve vasıtaya sahipse, o halk o kadar kültürlüdür. Onun kültürü o kadar daha zengindir. Bu mahiyette kültür, yani hars, sadece halka aittir (Tacemen, 1998, s.20). "Kültür gelenek, görenek, inanış, düşünce, bilim ve sanat etkinliklerinin birikimiyle ortaya çıkan ve her topluma göre değişen kavramdır" (Güz, 2002, s.121). 
"Hall’a göre (1959, s.169) kültür iletişimdir ve iletişim kültürdür. Gudykunst'a göre (1997) iletişim ve kültür karşılıklı olarak birbirini etkiler. Bireylerin içinde sosyalleştiği kültür, kurdukları iletişimi etkiler. Bireylerin iletişim yolları zamanla paylaştıkları kültürü değiştirir. Kültür bir grubun ortak sembol sisteminden geçerek kuşaktan kuşağa aktarılan öğrenilmiş ve paylaşılan davranışlar ve algıları olarak tanımlanır" (Erdoğan, 2002, s.132). Kültür bir anlamda insanın gittikçe karmaşıklaşan yaşamla mücadele edebilmesi için bilgiyi kodlama modelidir. "Burada bahsi geçen kodlanan bilgi iletişim araçlarıyla aktarılıp paylaşıldığı için kültür ve iletişimi birbirinden ayrı düşünmek mümkün değildir" (Baltaş, 2007, s.22). "Kültür bir toplumu oluşturan insanların bütün bir yaşam biçimi olarak tanımlanabilir. Söz konusu yaşam biçimi, insanlar tarafından üretilen maddi ve manevi nitelikteki tüm değerleri kapsar" (İnceoğlu, 2004, s.129). Sosyal miras ve gelenekler sistemi olarak kültür; varlığımızın yapısını (ilişkilerini) belirleyen, sosyal bir süreçle öğrendiğimiz uygulama ve inançların, maddi ve manevi öğelerin birliğidir. Hayat yolu ve biçimi olarak kültür; bir toplumun tüm hayat biçimidir. Kültür bir grubun yaşama biçimidir. İdealler, değerler ve davranışlar olarak kültür; sosyalkültürel evrendeki açık seçik eylemlerin ve araçların ortaya koyduğu ve nesnelleştirdiği anlamlar, değerler ve kurallar, bunların etkileşim ve ilişkileri, bütünleşmiş ve bütünleşmemiş gruplarıdır (Güvenç, 1974, s.101).

Haviland'a göre "toplum; ortak bir kültürü paylaşan, hayatta kalmak için birbirine bağl1, belirli bir bölgede yaşayan insan grubu"dur. Toplumu bir arada tutan ilişkiler bütünü sosyal yapıdır. Kültür ve toplum kavramları birbiriyle yakından ilişkilidir. Haviland "Bireysiz bir toplum olamayacağı gibi kültürsüz bir toplum da düşünülemez." der. İnsan “toplumsal bir varlık” olarak tanımlandığında değil, "kültürel bir varlık" olarak tanımlandığında diğer canlılardan ayrı ve ayrıcalıklı olabilmektedir (Zillığlu, 2003, s 46).

Kültürün kuşaktan kuşağa aktarımı dil, sözlü ürünler, yazılı belgeler, edebi eserler, tarihi eserler, araçlar-gereçler, görsel ve işitsel materyaller vb. unsurlarla gerçekleşirken bu aktarımın en doğal biçiminin “yaşayış" olduğunu rahatlıkla söyleyebiliriz. Birey, içine doğduğu toplumun kültürel kodlarını yaşayarak öğrenir. Toplumun beklentilerine uygun davranışlar sergilemesi, toplumdan dışlanmaması ve o yapının bir parçası olabilmesi için kültürünün gereklerini doğru öğrenmesi gerekir. $\mathrm{Bu}$ öğrenme süreci aile içinde başlar, sosyal ortamda devam eder. Kültürel kodların öğrenilmesinde en etkili araçlardan biri oyunlardır. Oyunlar yaş grupları ve cinsiyetlere göre değişkenlik göstermekle birlikte çocukluktan erişkinliğe, erişkinlikten yaşlılığa kadar bireye eşlik eder. Eğlendirme işlevinin yanında, eğitme ve birleştirme özellikleri açısından oyun kavramını incelemek faydalı olacaktır.

\section{Oyun}

İlk insan henüz hiçbir şey bilmediği dönemlerde, tabiat içinde yaşarken, bir takım sesler duymuş, hareketler görmüştür. Zamanla bu hareket ve sesler kafasında çeşitli çağrışımlar yapmış ve insanoğlu taklit etmeye başlamıştır. İlk insanlar oyunla düşünce, tasavvur, arzu, ihtiras ve efsanelerini anlatmışlardır. Böylelikle ses ve hareketin bütünü olan "oyun” ortaya çıkmıştır (Ay, 1999, s.161). Ay’ın oyunun ortaya çıkışı ile ilgili bu savı, insanın oyunu başlangıçta eğlenmek için değil, iletişim ihtiyacını karşılamak amacıyla kullandığını vurgulamaktadır. Artun'un tanımında ise oyunun sanat yönü öne çıkmaktadır. "İlk insan duygu ve düşüncelerini ifade için tabiat ve hayvan sesleriyle, jest ve mimiklerden faydalanarak taklidi meydana getirmiştir. Taklit, zaman içinde temsili doğurmuştur. Sözden önce başlayan bu taklit, sonraları hayatı hareket halinde göstermeye çalışan dram sanatının nüvesi olmuştur” (Artun, 1987; Elçin, 1977). “Oyun ilkel insanın yaşamı ve doğayı öğrenmekte 
kullandığı ilk etkinliktir. İlkel insanın, bulunduğu çevreyi tanıması, öğrenmesi, bilgi edinmesi ve sanatsal becerisi ilk olarak oyunla birlikte başlamıştır. Uygarlık geliştikçe oynayan insana ayrıca düşünen ve karar veren insan olgularının da eklenmesi oyunu genellikle fikir jimnastiği (mantıksal bir sistem) denilen ve düşüncenin sonucu ortaya çıkan bir kavram durumuna getirmiştir" (Bekar, 2001, s.5). "İnsan; düşünen, anlayan, hisseden, yaratan, kendini ve etrafını değiştirip düzenleyebilen, anlamlandıran, yorumlayıp, yargılayan, bilen ve bildiğini aktarabilen, kendine özgü (nevi şahsına münhasır) ve özgür olan bir varlık türüdür" (Açıköz, 2003, s.40). "Oyuncu insan, yaşamın zorlu aşamalarına hazırlanırken oyunun kendine özgü niteliklerinden yararlanır. Oyun hayal dünyasından gerçeğe uzanan bir köprüdür. İnsan yavrusu bu köprüden geçerken hayattan haz almayı, zorluklarla mücadele etmeyi ve ait olduğu topluma nasıl uyum sağlayacağına yönelik pratikleri kazanır" (Yanık, 2010, s.38). "Oyun, anlamı ve toplumsal işlevi olan bir etkinlik biçimidir. Ve çeşitli toplumlardaki törelerin, anlayışların, sözlü gelenekteki kuralların kaynağı da oyundur” (Nutku, 1998, s.19). “Oyun, toplumun duygu ve düşüncelerini yansıtan ve onları birbirine yaklaştıran, kaynaştıran bir unsurdur. Dolayısıyla o milletin karakterini yansıtır" (Çakır, 2009, s.53). Huizinga'ya göre (1995, s.17) ise "her oyun bir anlam taşır. Eğer oyuna bir öz yükleyen bu faal ilkeye zihin dersek aşırıya kaçmış oluruz; eğer ona içgüdü dersek hiçbir şey söylememiş oluruz. Hangi açıdan ele alınırsa alınsın, oyunun bu kasıtlı karakteri, bizatihi özünün içinde yer alan maddi olmayan bir unsurun varlığını açık etmektedir."

“Oyun aynı zamanda kültürün evrelerini var eder. Her kültürde her oyunun belli hareket nitelikleri vardır ve günlük yaşamdan farklıdır. Oyunlar, insanların yaşam biçimlerinden kaynaklanır ve yaşamdan farklı bir biçimde ortaya çıkar (Nutku, 1998, s.19). "Oyunun, hayatı taklitten ibaret olduğu her durumda, bir yandan oyuncu, gerçekleri içermediği kuralları doğallıkla icat edemez ve izleyemez, öte yandan da oyun, takınılan tavrın bir benzeşim, basit bir taklit olduğu bilincine eşlik eder. Üstlenilmiş davranışın temel gerçek dışılığına ilişkin bu bilinç, başkaca oyunları tanımlayan keyfi yasallığın yerine ve yerinde, insanı gündelik hayattan ayırmaktadır” (Ilgaz, 1994, s.41). Oyun, bedenin eğitilmesi, işitme-görme-dokunma ve hareket koordinasyonu oluşturma, toplumsal rollerin kazanılması, sosyal bilincin oluşturulması, ruhsal ve sinirsel gerginliğin azaltılması veya tamamen ortadan kaldırılması, hayal gücünün güçlendirilmesi, sözlü ve sözsüz kültür ürünlerinin geleceğe taşınmasında aktif rol oynar. Yaygın kanaatin aksine oyun salt bir eğlence aracı olmanın ötesinde, eğitim, iletişim, sosyalleşme, ruhsal gerginlikten kurtulma gibi pek çok önemli işleve sahiptir. Farklı disiplinler, oyun kavramının işlevlerinden farklı şekillerde faydalanmaktadırlar. "Oyalanma yanında, günümüzde oyun çeşitli uğraşlara, yöntemlere, bilim dallarına yardımcı olmaktadır. Askerler savaş oyunları oynarlar, iş adamları, borsacılar endüstri alanında pazarlama gibi konularda oyunlar düzenlemektedirler. Oyuna, psikiyatride sağaltma için, davranışları inceleyen bilimlerde yeni bir toplumbilim kavramı olan boş vakitleri değerlendirmede, geri kalmış çocukların sağaltılmasında eğitimde çok başvurulmaktadır. Özellikle eğitimciler, oynayarak öğrenmenin daha ilginç olduğunu, katılma ile daha çok öğrenildiğini, öğrenilenlerin daha iyi bellekte kaldığını, eleştirel düşünce, karar verme ustalığını daha iyi kazandırdığını, davranışları değiştirdiğini saptamışlardır.” (1. Uluslararası Türk Folklor Semineri, S.306)

Göstergebilimci Mehmet Rifat (1996, s.11), "Homo Semioticus” adl1 eserinde, Homo Semioticus'u "anlamlandıran insan" olarak tanımlamaktadır. Anlamlandıran insan; dünyadaki anlamların oluşumunu, birbirine eklemlenerek yepyeni anlamlar yaratmasını sorgulayan insandır. Çevresindeki bireysel, toplumsal, kültürel gösterge dizgelerini yalnızca betimlemekle yetinen değil, 
bu dizgelerin üretiliş sürecini yeniden yapılandıran insandır. Homo Semioticus, "hem dünyanın insan için hem de insanın insan için taşıdığı anlamı/anlamları" kavramaya çalışan ve üretiliş aşamalarını bir söylem içinde yeniden anlamlandıran insandır. Homo semioticus okuyan, adlandıran, anlamlandıran ve bütün bu işlemleri bir "oyun" oynayarak, yani hem haz duyarak hem de haz vermeye çalışarak yapan insandır. Mehmet Rifat'ın; anlamlandırma işlemini haz duyarak ve haz vermeye çalışarak yapan insanı "oyun oynayan insan"a benzetmesi aslında tesadüf değildir. Anlamlandıran insan bu işlemi oyun disiplini içinde yaparken, oyun oynayan insan da çevresini, yaşadığı dünyayı, çevresinde gelişen olayları oyun yoluyla yeniden anlamlandırmaktadır. Dolayısıyla "Homo Semioticus yani anlamlandıran insan ile Homo Ludens yani Oyuncu/ Oyun oynayan insan arasında önemli bir ilişki vardır" dersek yanlış olmaz. Zira oyun; bilimsel, sanatsal, bedensel ve fiziksel bir etkinlik olarak insana gerçek yaşamı yeniden üretme, anlamlandırma imkânı sunmakta ve bu kavramla birlikte gerçek dünyanın dışında çok daha renkli bir dünyanın kapılarını aralamaktadır. "Oyun özgür bir eylemdir, bilinçli olarak günlük yaşamın dışında kalır, ciddî bir iş olarak benimsenmemekle beraber, oyuncu yoğun olarak kendini oyuna verir. Bu eylemden maddî bir kazanç, bir kâr, bir çıkar beklenmez. Oluşumu, kendi zaman ve yer sınırlanması, saptanmış kuralları ve düzeni içindedir. Çoğunlukla dış dünyadan kendilerini kılık değiştirme ve başka yollarla ayırır ve oyuncuları, aralarında gizli bağlarla birleştirir, toplumsal öbekleşmeyi kolaylaştırır.” (And, 1974)

"İletişim toplumsal yaşamı olanaklı kılar, bu nedenle toplumsal yaşamın temelidir. İletişim olmadan iletişim toplumu olamazdı. Buna bağlı olarak tüm insan toplumlarını birbirleriyle ilişkili iletişim ağları gibi düşünebiliriz. Tüm insan etkinlikleri iletişimle sürdürülür ve değiştirilir. Bireyler doğuşta hazır buldukları bu iletişim ağları içinde birbirleriyle şeyler, olgular ve olaylar hakkında biçimlenmiş ya da kendilerinin biçimledikleri anlamların değiş tokuşunu yaparlar, ilişkilerini düzenlerler" (Zıllığlu, 2003, s.13). Anlamların paylaşıldığı en etkili ortamlardan biri hiç şüphesiz insanların bir araya gelmesini sağlayan toplantı ve eğlencelerdir.

\section{Yöntem}

Çalışmada “tarama (survey) modeli” uygulanmıştır. Konuyla ilgili geniş kapsamlı bir literatür taraması yapılmıştır. Oyunlarla ilgili görsel kaynaklar (fotoğraf, video) incelenmiş, geleneksel eğlence hayatında kadın toplantı ve eğlencelerinde oynanan oyunlar tespit edilmiş, oyunlar içerdikleri mesajlar yönüyle iletişimsel açıdan yeniden değerlendirilmiştir.

\section{Bulgu ve Yorumlar}

\section{Gaziantep Yöresi Geleneksel Eğlence Hayatında Kadın Toplantı ve Eğlencelerinde Oynanan Oyunlar ve Bu Oyunların İletişim Boyutu}

Genel olarak oyunun oynanma amac1, yeri, nitelikleri farklılıklar gösterdiği için geleneksel oyun incelemelerinde bir sınıflandırmaya ihtiyaç duyulmaktadır.

1. Oyunun amacı ya da gerekçesi

2. Oyundaki eylem ve davranışlar

3. Eylem ve davranışların kuralları

4. Oyuna katılanların sayısı

5. Oyuna katılanların görev ve işlevleri 
6. Oyunun sonuçları, cezalar ve değerlendirmeler

7. Oyuncuların birbirleriyle ya da oyun gereç ve araçlarıyla eylem ilişkileri

8. Oyunda eylem için gerekli yetenek ve beceriler

9. Oyunun yeri, insan eliyle yapılan oyun yeri ya da doğal çevre

10. Oyunda doğal ya da insan yapısı araç ve gereçler" (1. Uluslararası Türk Folklor Semineri, s.312)

Hemen her yörede olduğu gibi genellikle eğlenmek, bir arada hoşça vakit geçirmek için gerçekleştirilen toplantılar Gaziantep yöresinde amaç/gerekçelerine göre; dini inançlar çerçevesinde yapılan ve ritüel özelliği taşıyanlar, zamana göre değerlendirildiğinde gece veya gündüz yapılanlar, geçiş dönemleri ile ilgili düşünüldüğünde evlilik, sünnet düğünleri vb. kapsamında yapılanlar, toplantının tertipleniş durumuna göre; yemekli-yemeksiz, müzikli-müziksiz yapılanlar, mekan açısından ev içi-ev dışı ve tüm bu sınıflandırmanın dışında kalan bağımsız toplantılar şeklinde siralanabilir.

Cinsiyet çerçevesinde ele alındığında toplantı ve eğlenceler;

1. Kadın toplantı ve eğlenceleri

2. Erkek toplantı ve eğlenceleri

3. Kadın-Erkek birlikte yapılan toplantı ve eğlenceler olarak değerlendirilmektedir.

Konuyla ilgili kaynaklarda Gaziantep’te kadınların özellikle kış geceleri komşularda toplandıkları ve eğlence tertipledikleri belirtilmektedir. Bu eğlencelerde daima oyunları iyi bilen, oyun çıarmaktan anlayan birileri bulunmaktadır. Bunların ortaya koydukları oyunlar saatlerce devam eder, ardı arkası kesilmez. Bu tür toplantılara erkekler gelmezler.” (Atalar, ?, s.19) Gaziantep'in önemli kültür araştırmacılarından Gonca Tokuz, oyunlara iştirak eden katılımcıların özelliklerinden bahsederken bazı oyunların ortak oynandığını ifade etmektedir. "Toplantı ve eğlencelerde oyunlar önemli bir yer tutar. Oynanan oyunların bir kısmı ortak oyunlardır. Kadın ve erkek birlikte oynanan oyunlara; Yüzük Oyunu, Peçiç Oyunu, Soğan Kalktı Havuca oyunu gibi oyunlar örnek verilebilir. Bu oyunlardan Yüzük oyununa çocuklar da katılabilmektedir. "Karaoğlan” ve "Tuman” gibi oyunlar kadınlara, "Seni Gidi Gergiden”, "Bir Karalı Mamet Ağa” gibi oyunlar da erkeklere özgüdür. Kadın oyunu olan mentivarın yaygın olmamakla birlikte, bazı erkek toplantılarında gençler arasında oynandığı da ifade edilmiştir. Genelde büyükler oyun oynayıp eğlenirken, çocuklar da ya bahçede, ya da evin bir başka köşesinde, kendi aralarında oynayıp eğlenmektedir.” (Tokuz, 2004, s.16). Atalar, Gaziantep'te toplantı ve eğlencelerde oynanan kadın oyunlarının özelliklerini kostüm, müzik ve söz unsurlarıyla sıralamıştır. Örneğin kadın oyunlarının en büyük özelliği bu oyun içerisinde daima erkek kılığına girmiş bir kadının bulunması ve oyunun sonunda kadının erkeğine bağlılı̆̆ının anlatılmasıdır. Bu oyunların bir diğer özelliği de belirli bir müzik aleti bulunmamasının yanında, zaman zaman darbuka ve tef kullanılmasıdır. Genellikle oyun sırasında kullanılmayan bu müzik aletleri oyun aralarında ve oyuna girişte heyecanı artırmak amacıyla çalınmaktadır. Ve hemen her oyunda oyunla ilgisi olsun olmasın bir mani söylenmektedir. Mani dışında oyunun içeriğine göre ağıt okunduğu da belirtilmektedir. (Atalar, s.19)

Beden, duygu ve düşünceleri yetkin bir biçimde dile getirebilen bir araçtır. Oyuncu bedeniyle iç coşkusunu dişa yansıtır. Bunu yaparken sadece bedenini kullanmaz, zaman zaman sözcüklere başvurur, araç ve gereç kullanır, ahenkli sesler ve çeşitli nidalarla bedenine eşlik eder. Aşağıda 
Gaziantep yöresinde kadınların çeşitli vesilelerle gerçekleştirdikleri toplantılarda oynadıkları oyunlar, bu oyunların hareket ve söz ile birlikte iletişim boyutuyla ilgili özellikleri verilmektedir.

Mentivar Oyunu: Sözcük anlamının “Mart Falı” olduğu, değişime uğrayarak halk arasında "Mentivar" olarak söylendiği sanılmaktadır. Gaziantep'te özellikle kadın toplantı ve oyunlarında önemli bir yere sahip olduğu belirtilmektedir. Oynanış şekli şöyledir; "oyuna katılan kadınlardan birer adet takı (yüzük, kolye veya bilezik) alınır, bir torbaya konur. Torba küçük bir çocuğa veya kadınlardan birine verilir. Torbadan sıra ile bir takı çıkartılır ve bu arada mani söylenir. O sırada kimin takısı çekilmişse, maninin anlamı takı sahibinin niyeti sayılır, yorumlanır, anlamlandırılır, şakalar yapılır. Maniler okunmadan önce, her maninin başında aşağıdaki mentivar dörtlüğü mutlaka söylenir. Torbadaki takılar bitince oyun da biter.

Mentivar Dörtlüğü:

$$
\begin{aligned}
& \text { "Ey mentivar mentivar } \\
& \text { Mentivarın vakti var } \\
& \text { Mentivar söyleyenin } \\
& \text { Cennette beş tahtı var" (Tokuz, 2004, s.24) }
\end{aligned}
$$

\section{Mentivar Oyunu sırasında söylenen maniler:}

"Mercimek kile kile

Ölçerim sile sile

Yar kapıya gelince

Çıkarım güle güle

Irahan ektim duvara

Kim kaza kim suvara

Yarim küçük ben küçük

Bizi kimler uyara

Irahan ektim gül bitti

Dalında bülbül öttü

Ötme bülbülüm ötme

Yarim sefere gitti

(Tokuz, 2004, s.25-26)
İncecik yesmin dalı

Dibinde yeşil halı

Doğru yolu sen göster

Ya Muhammed, ya Ali

Dam üstünde durursun

Samur kürkün sürürsün

Mevla'm sana bir vermiş

Altın beşik ürgürsün

Gül koydum gül taşına

Hayatın ortasına

Yarim bir gül sokunmuş

Zülfünün ortasına
Ey havayı havayı

Kendir çeker kuvayı

İki garip güvercin

Yeni yapar yuvayı

Ayna attım çayıra

Şavkı düștü bayıra

Yarim küçük, ben küçük

Bizi Mevla'm kayıra

Hey hezine hezine

Oturmuş yel üstüne

Kürkü çekmiş dizine

it bile bakmaz yüzüne"

Oyunda kısmetine hangi maninin çıkacağının bilinmemesi, heyecan unsurunu artırır. Maniyle eşleşen takı sahibinin durumuna uygun olarak maninin yorumlanması okuyucunun iletişim becerilerine bağlıdır. Aynı zamanda izleyiciler de toplantıya katılanların özel durumları, yaşamlarının paylaşılmaya açık kısımlarıyla ilgili bilgi sahibi olurlar.

Yörede sıkça oynanan oyunlardan biri de gelin-kaynana ilişkilerini anlatan oyunlardır. Günlük yaşamda dertlerini dillendiremeyen gelinler ve kaynanalar veya onların yakınları oyunda söylenen maniler, sataşmalar ve imalarla eğlenme ve rahatlama imkânı bulurlar. Oyunda söylenen maniler zaman zaman müstehcen sayılabilecek hatta hakaret olarak kabul edilecek ifadeler taşırlar. Oynayanlar bunun bir oyun olduğunun bilincindedir. 
Gelin Kaynana Oyunu: Gelin kaynana çekişmesini anlatan oyunlarda çoğunlukla gelin haklı olmasına rağmen ağız kavgaları çıkar, ama kaynana daha baskın çıkar. Sonunda gelinin kocası olaya el koyar ve karısını korur. Bazen de koca oyunda hiç görülmez ve kaynana haksızlığını anlayarak gelinle barışmak ister. Bu tür oyunlar genellikle çıkarma oyunlardır. (Atalar: 22; Tokuz, 2004, s.39-41) Ritüel kökenli eğlenceler, mesleki (çoban,çiftçi vb.) ve bireysel (taklit yeteneği olan, iletişim kabiliyeti gelişmiş, ağzı laf yapan, geleneğe hakim) ölçütlere göre , gelenekte doğal olarak görevlendirilmiş ya da bu işe talipli kişiler tarafından hazırlanmakta ve gerçekleştirilmektedir. (Özdemir, 2005, s.115) Hemen her oyunda olduğu gibi gelin kaynana oyunlarında da mani söylemede, oyunu sergilemede yetenekli olduğu düşünülen insanlara öncelik verilir. Bedensel hareketler doğaçlama olarak gelişir, manilerde ise belli kalıplar söz konusudur.

Tokuz, 20. Yüzyılda Gaziantep eğlence hayatını anlattığı kitabında Gaziantep ve Kilis yöresinde söylenen manilerden örnekler vermektedir.

\section{Kaynana:}

"Eli zilli gelin

Koltuğu dertli gelin

Oğlanı ben doğurdum

Sahtiyan yüzlü gelin (kara yüzlü gelin)"

"Tağaları demir gelin

Ne buyurdun emir gelin

$\mathrm{Bu}$ oğlanı ben doğurdum

Gel g...mü gemir gelin (Kilis’ten bir örnek)"

\section{Gelin:}

Çarşıda nişe kaynana

Batmanı beşe kaynana

Oğlun beni çok sever

Altına işe kaynana

Ekinlikte çiçekler

Yük yerinde döşekler

Kaynanadan giymatlı

Ahırdaki eşekler" (Tokuz, 2004, s.41)

Oyunu oyun yapan özelliklerden biri de içinde barındırdığı paylaşma duygusudur. Bir oyunu paylaşmak keyif veren bir şeydir. Üstelik paylaşma yaratıcılığa da özendirir. Oyunun büyüsü paylaşma, beraberlik duygusuyla gelişir, renklenir, büyür ve sonunda ortak bir yaratıcılığa yönelir. Bu birliktelik takım ruhunu, birlikte bir şeyler üretme hazzını sağlar. Gündelik yaşamın tekdüzeliği karşısında, bir süre için de olsa insana yaşama sevinci veren şeydir oyun. Bu açıdan, yaşamın da özüdür (Nutku, 1998, s.32, 33). Oyunlar zaman zaman toplumsal yaralara da değinir.

Gaziantepyöresi kadın oyunlarından bazıları da poligami (çok eşlilik) olaraknitelendirdiğimiz, halk arasında "kuma" şeklinde ifade edilen soruna işaret eder. Bahteniz (Maydonoz) Bacı adıyla oynanan bu oyunda çocuğu olmadığı gerekçesiyle başka bir kadınla evlenen kocasının ardından üzüntü, sıkıntı çeken Bahteniz bacının yaşadıkları dramatize edilir. Oyun iki kadın tarafından, karş1ıklı manili ve türkülü atışmalar şeklinde gerçekleştirilir. Kadının bedensel hareketleri genelde dövünme ve kocasına ilenme şeklindedir. Oyunun sonuna doğru manilerde, başka kadınla evlenip ondan çocuğu olan kocanın çocuğunu kaybetmesi, yuvasının dağılması hikaye edilir. Böylelikle mağdur olan Bahdeniz bacı sevinir ve daha güçlü bir görünümle, günlük işlerini şevkle yaptığını gösteren beden diliyle mutluluğunu paylaşır. (Kaya, 1972, s.20-22; Tokuz, 2004, s.41; Atalar, ?, s.22-24)Gerçek yaşamda sorununa çare bulamayan kadınlar bu oyunda ilahi adalet duygusunu yansıtmakta ve "yuva yıkanın yuvası olmaz" düşüncesini bir iletişim aracı olarak oyunu kullanmak suretiyle aktarmaktadırlar. 
İnsan yaşamının önemli geçiş dönemlerinden biri olan evlenme adetleri ve bu adetler içinde yer alan, Gaziantep yöresinde de düğür gelme (kız isteme) olarak adlandırılan adetin güldürü boyutuyla ele alındığ 1 oyunlar da mevcuttur. Her oyunda olduğu gibi bu oyunda da canlandırma yapan oyuncuların kabiliyeti, jest ve mimik kullanımındaki başarıları ön plana çıkmaktadır. "Dramatik köy oyunlarında oyuncu o toplumun bir bireyidir. Bir gerekliliği ve kutsal olanı yerine getirdiği için, oyuncu gözü ile bakılmaz. Toplumun diğer bireylerinden ayrılmadığı için hiçbir ayrıcalığa da sahip değildir. Oyuncular yaşadıkları toplum birimlerinde istekli, yetenekli kişilerdir. Sosyo-ekonomik konumlarıyla diğer toplum birimlerinden ayrılmazlar. Ancak bazı yörelerimizde oyunculuk profesyonel bir iş koluna dönüşmüştür. Bunlar; düğünlerde çalgı ihtiyacını karşıladıkları gibi, çıkardıkları oyunlar, güncel yaşam sorunlarını kapsayan ve profesyonel hazırlığı öngören bir uğraş içindedirler" (Sağlam, 1999, s.60).

Kız Sana Düğür Gelmişler, Garı Kıza Tepsi Geldi oyunlarında evde kalmış kızların alaya alınması söz konusudur. Genellikle çirkin ama çirkinliğini kabul etmeyen, hatta kendini beğenmiş bir kızla çevresindekilerin ya da çoğunlukla seçilmiş bir diğer kişinin atışmaları oyunu şekillendirir. Oyunda kişilerin kusurlarını yadsımaları vurgulanmakta, kusurlu kişilerin iç ve dış dünyalarındaki eksiklikleri bilinçli olarak reddetmeleri eleştirilmektedir. Burada çirkinlik ya da bedensel sakatlık semboliktir. Oyunla verilmek istenen mesaj kusurlarını görmezden gelen, kendiyle barışık olmayan ya da hatalarını düzeltmek yerine çevresiyle çatışmayı tercih eden insanların toplum içerisinde düşecekleri komik durumdur. Bu oyunlardan "Kız Sana Dügür Geldiler” oyununda bir gözü kör, bir eli çolak, bir ayağı topal, sırtı kambur, eli sopalı kız ile komşu kadın arasında geçen diyalog örnek olarak aşağıda verilmiştir.

$\begin{array}{ll}\text { Kadın } & \text { : Kız sana düğür geldiler } \\ \text { Sakat Kız } & \text { : Hani ya nerde kaldılar } \\ \text { Kadın } & \text { : Geldiler de gittiler } \\ \text { Sakat Kız } & \text { : Ne ayıbımı gördüler } \\ \text { Kadın } & \text { : Gözüne de kör dediler } \\ \text { Sakat Kız } & \text { : Hani ya da gözüm kör mü? (diyerek izleyiciler arasında dolaşır.) }\end{array}$

Oyun, kızın tüm kusurlarının sayılması ve bunlara verilen tepkiler üzerine devam eder (Kaya,1972, s.22).

Evlilik dışı ilişkinin sakıncalarını vurgulayan "Komşunun Oğlu” oyunu üç kadın tarafından oynanır. Biri baba, biri anne, bir diğeri de evin kızını canlandırır. Kilis’te oynandığı ifade edilen oyunun daha çok kına gecelerinde sergilendiği belirtilmektedir. Evin kızının sıklıkla ortadan kaybolması ve eve her dönüşünde komşunun oğlunun kendisini öptüğü, elini tuttuğu, yanağını okşadığı gibi çeşitli münasebetlerini anne ve babasının soruları üzerine cevapladığı oyunun sonunda kızın hamile kaldığ1 (karnına bir yastık yerleştirilerek) gösterilir. Kızın karnındaki yastık düştüğünde çocuk doğmuş olur ve oyun anne-babasının kızı kovalamasıyla son bulur (Atalar, ?, s.26).

Eşe olan bağlılığın ifade edildiği oyunlar da mevcuttur. "Don Oyunu” ve "Ölü Oyunu” içerik olarak bu tür oyunlara örnek gösterilebilir. Don oyununda bir kadın oyuncu eline erkek iç çamaşırı alır, oyun boyunca elindeki çamaşırı sallar ve oyunun türküsünü söyler: 
"Bu don kimin donu

Kaynanamin donu

Şarmitanın donu

Ben yıkamam onu” türkünün sözleri değişmez, sadece donun sahibi değişir. Elti, kayınbirader, kayınbaba şeklinde sözler devam eder. Son olarak;

"Bu don kimin donu

Herifimin donu

Ben yıkarım onu

Gül dalına asarım" onu diyerek türkü ve oyun sonlandırılır.

Ölü oyununda ise iki oyuncu vardır. Bunlardan biri erkek kılığına girer. Diğeri karısı rolündedir. Erkek kılığındaki kadın seyircilerin arasında otururken birden "ben öldüm” diyerek kendini yere atar. Karısı da peşinden kendini yerden yere vurarak ağlamaya başlar. Ağıtlar söyler. Ağıtlar bitince ölü taklidi yapan oyuncu dirilir. Mekândakiler sevinç belirtisi olarak zılgıt çalarlar. İki oyuncu ve diğer izleyiciler darbuka ve def eşliğinde çeşitli türküler söyleyerek oynarlar.

\section{Sonuç}

Oyun iletişimdir ve insanlar için vazgeçilmez bir ihtiyaçtır. Oyunun iletişimle eş tutulmasının haklı gerekçeleri vardır. Oyun, iletişim gibi kendine özgü araçlara sahiptir. Anlam aktarımı ve paylaşımı bu araçlar aracılığıyla yapılır. Oyunun en önemli aktarım aracı bedendir. Beden, müzik ve ritim eşliğinde mesajları iletir. Bu iletim sırasında çeşitli yardımcı araçlar devreye girer. Giysiler, aksesuarlar, çeşitli sesler, nidalar, hareketler iletilerin aktarılmasında yardımcı rol oynarlar. Oyunun geçmişi insanlık tarihi kadar eskidir. Oyun ve oyunla anlatılanlar geçmişten, bugünden ve geleceğe dair beklentilerden izler taşır.

Oyun kavramı kültürle şekillenir ama aynı zamanda şekillendiği kültürün taşıyıcısıdır. Kuşaktan kuşağa aktardığı iletilerle kültürün devamlılığına katkı sağlar. Oyunun iletişim yönü oyuncularla beraber çevrede bulunan herkesi etkisi altına alır. Oyunu oynayan ile izleyici arasında da güçlü bir bağ vardır.

Gaziantep yöresi kadın eğlence ve toplantılarında oynanan oyunların içeriğinde hayata dair dersler vardır. Gençler oynanan oyunlardan kendilerine ders çıkarırken, yörede kabul gören ya da ayıplanan durumlar, davranışlar, eylemler hakkında da fikir sahibi olurlar. Toplantılara katılan kadınlar gözlemlerini, tecrübelerini, umutlarını, beklentilerini dramatize ederek oyunlar aracılığıyla birbirlerine aktarırlar. İletişimin özünde yatan paylaşma, anlaşma, etkileşim, haberleşme vb. unsurlarını gerçekleştirmiş ve beraberinde eğlenmiş olmanın verdiği hazla, ruhsal ve psikolojik açıdan doyuma ulaşırlar.

Özdemir, "günümüzün kent yaşamında, "çalışma hayatının özel yaşam üzerindeki belirleyiciliğinin artması, bireyselliği özendiren farklı eğlence seçeneklerinin yaygınlığı, kamusal alanlardaki çözülme ve yok olmalar, etkisini yitiren komşuluk ilişkileri, çekirdek aile türünün 
yaygınlaşması gibi” olgulardan dolayı pek sık olarak gerçekleştirilemeyen kış toplantı ve eğlencelerinin özellikle köy, kasaba gibi küçük yerleşim birimlerinde gelenekselleşen kültürel bir olay olarak yaşatıldığı belirlenmiştir.” der (Özdemir, 2005, s.51). Bu durum maalesef Gaziantep için de geçerlidir. Özellikle televizyon ve gençler arasında yaygın olan internet kullanımının eğlence anlayışını büyük ölçüde değiştirmesi sebebiyle sözü edilen oyunlar yok olmaya yüz tutmuştur.

Üniversitelerin ilgili alanları, Valilikler, Belediyeler, STK'lar, Dernekler vb. kurum ve kuruluşların çabalarıyla gerçekleştirilen etkinlikler, çalışmalar umut vericidir. Gelişen teknolojinin imkanları doğru kullanıldığında insanı yalnızlaştıran teknoloji, insanın paylaşma hazzını yeniden duymasını sağlayacaktır.

\section{Kaynakça}

Artun, E. (1987). Tekirdağ köy seyirlik oyunları. III. Milletlerarası Türk Folklor Kongresi Bildirileri / Halk Müziği, Oyun, Tiyatro, Ĕglence, Kültür ve Turizm Bakanlı̆̆ı Milli Folklor Araştırma Dairesi Yayınları. Ankara: Başbakanlık Basımevi.

Atalar, A. (?). Gaziantep Kültüründe Oyun. Gaziantep Büyükşehir Belediyesi Kültür Serisi.

Ay, G. (1999). Folklor (Halkbilim) genel bilgiler, oyun, müzik. İstanbul: Pan Yayınc1lık.

Baltaş, Z. (2007). Bedenin dili (40. b.s). İstanbul: Remzi Kitabevi.

Bekar, C. (2001). Eğitimde oyunun çocuğun gelişimine etkileri. Folklor, Halkbilim Dergisi, Cilt: 5, Sayı: 49, İstanbul.

Çakır, A. (2009). Tozlu adımlar. Ankara: Kültür Ajans Yayınları.

Elçin, Ş. (1977). Anadolu Köy Orta Oyunları, Ankara.

Erdoğan, İ. (2002). İletişimi anlamak. Ankara: Erk Kitabevi.

Eroğlu, T. (1995). Doğu ve Güneydoğu Anadolu'da halkoyunlart ve halayların incelenmesi, Ankara.

Gökçe, O. (2006). Illetişim bilimi, insan iliş̧kilerinin anatomisi. Ankara: Siyasal Kitabevi.

Güvenç, B. (1974). İnsan ve kültür. İstanbul: Remzi Kitabevi.

Güz, N. (2002). Etkili iletişim terimleri. İstanbul: İnkılâp Kitabevi.

Haviland, W. (2002). Kültürel antropoloji. İstanbul: Kaknüs Yayınları.

Huizinga, J. (1995). Homo Ludens (M. A.Kllı̧̧bay, Çev.). İstanbul: Ayrıntı Yayınları.

Ilgaz, T. (1994). Oyun, Mimesis Çeviri ve Araştırma Dergisi, No:2, İstanbul.

İnceoğlu, M. (2004). Tutum, algl, iletişsim. Ankara: Elips Kitap.

Kaya, M. (1971-1972). Gaziantep yöresi seyirlik oyunları. Yayınlanmamış lisans tezi, Ankara Üniversitesi Dil ve Tarih Coğrafya Fakültesi Tiyatro Kürsüsü.

Nutku, Ö. (1998). Oyun, çocuk, tiyatro. İstanbul: Özgür Yayınları.

Özdemir, N. (2005). Cumhuriyet dönemi Türk eğlence kültürü (1.b.s.). Ankara: Akçağ Yayınları.

T.C. Başbakanlık Kültür Müsteşarlığı Milli Folklor Enstitüsü Müdürlüğü, 8-14 Ekim 1973. 1. Uluslararası Türk Folklor Semineri Bildirileri (1974), Ankara: Başbakanlık Basımevi.

Rifat, M. (1996). Homo Semioticus. İstanbul

Sağlam, Y. (1999). Oktay Arayıcı'nın oyunlarında geleneksel tiyatro öğeleri. Ankara: Kültür Bakanlığı Yayınlar1.

Tacemen, A. (1998). Türk Kimliği, Niğde Üniversitesi Yayınları, Niğde. 
Tokuz, G. (2004), 20. Yüzyılda Gaziantep’te Eğlence Hayatı, Gaziantep Üniversitesi Basımevi, Gaziantep.

Tutar, H., M.K. Yılmaz, C. Erdönmez (2004). Genel ve Teknik İletişim. Ankara: Nobel Yayın Dağıtım.

Yanık, E. (2010). Dans ve iletişim. Yayımlanmamış yüksek lisans tezi, Sakarya Üniversitesi Sosyal Bilimler Enstitüsü Türk Dili ve Edebiyatı Anabilim Dalı, Halk Bilimi Bilim Dalı.

Zıllığlu, M. (2003). İletişim Nedir (2. b.s.). İstanbul: Cem Yayınevi. 